\begin{tabular}{|c|c|c|}
\hline \multirow{3}{*}{$\mathbb{H}^{E M}$} & KEMAS 15 (2) (2019) 269-275 & OKEMAS \\
\hline & Jurnal Kesehatan Masyarakat & $=$ \\
\hline & http://journal.unnes.ac.id/nju/index.php/kemas & $\overline{E--\min =-1}$ \\
\hline
\end{tabular}

\title{
Implementation of Hazard Analysis Critical Control Point Nutrition Service at Toto Kabila Regional Public Hospital, Bone Bolango
}

\author{
Sunarto Kadir ${ }^{\bowtie}$, Safira Amalia \\ Faculty of Sports and Health, Universitas Negeri Gorontalo
}

\begin{tabular}{l} 
Article Info \\
\hline Article History: \\
Submitted September 2019 \\
Accepted November 2019 \\
Published November 2019 \\
\hline Keywords: \\
HACCP, Critical Points, \\
Food Management \\
\hline DOI \\
https://doi.org/10.15294/ \\
kemas.v15i2.21222
\end{tabular}

\begin{abstract}
Hospitalized patients are very susceptible to various food-borne diseases. Food management in the hospital needs more careful attention. Hazard Analysis Critical Control Point (HACCP) is a preventive control system based on identification of critical points in the management and production of food as a way to ensure food safety. The objective of this study is to identify the implementation of HACCP principles in nutritional and dietetic service of RSUD Toto Kabila, Bone Bolango. This qualitative study employed descriptive survey method with HACCP as the study focus. The informants consist of eight people; three people as key informants and five people as triangulation informants obtained by purposive sampling. Data were analyzed using Miles and Huberman method, in which the collected data was written as matrix and then as checklist. The result revealed that nutrition and dietetics of RSUD Toto Kabila Bone Bolango was yet to implement HACCP according to the national standard (without documentation). This issue attributed lack of facilities and human resources at the department. It is suggested that the hospital implements HACCP according to the Indonesian National Standard as well as provides supporting facilities.
\end{abstract}

\section{Introductions}

Food safety is still an important issue in the food sector in Indonesia, and needs special attention in the food control program. Diseases and deaths caused by food in Indonesia are still high, although the principles of control for these diseases are generally known. Food control that relies on final product testing cannot compensate for the rapid progress in the food industry, and cannot guarantee the safety of foods circulating in the market. The traditional approach that has been done so far can be considered unsuccessful in overcoming the problem (Sudarmaji, 2005).

Hospitals have nutrition installation which is a place for organizing food for patients. Hospitalized patients are very susceptible to various foodborne diseases. Markedly contaminated enteral feed, containing $10^{3}$ to $10^{9}$ gram negative bacilli/mL, had been reported to cause not only diarrhea, but also sepsis, pneumonia and urinary tract infections. Also, considerable evidence indicated that enteral feeding contaminated with bacteria may be the cause of severe nosocomial infection (Arias, Monge, \& Chávez, 2003).

Most cases of foodborne illnesses are classified as "acute." These cases are usually selflimiting and of short duration, although they can range from mild to severe. Gastrointestinal problems and vomiting are common acute symptoms of many foodborne illnesses. Deaths from acute foodborne illnesses are relatively rare and typically occur in the very young, the elderly, or persons with compromised immune systems (Buzby, 2002). Therefore, 
food management in the hospital requires more careful attention.

Hazard Analysis Critical Control Point (henceforth called HACCP) is defined as a scientific, rational, and systemic approach to identify, assess, and control hazards (WHO, 2005). It is a system of food safety management which focuses control on critical control points (Worsfold, 2001).It defines the term as a device to assess hazards and to establish a control system focusing on the prevention rather than the test of a final product. Every system of HACCP is able to accommodate changes, i.e., advancement in equipment design, processing procedures, or the development of technology. Furthermore, Indonesian National Standard (SNI) divided the system into 12 steps, namely: establishment of HACCP team, product description, identification of usage objectives, preparation of flow chart, confirmation of flowchart in the field, recording of all potential hazards, determining critical control points (henceforth called TKK), determining critical limits, preparation of monitoring systems for each TKK, determining corrective actions, determining verification procedures, and determining documentation (Badan Standarisasi Nasional, 1998).

In HACCP, the standard operating procedure (SOP) has a common goal, i.e., to attain an efficient, effective, consistent, and secure routine procedure. This also functions to improve the quality of service by fulfilling the established standard (Reni, 2012).

The regulation of the Minister of Health of Republic of Indonesia number 147/ Menkes/Per/I/2010 defined the term hospital as an institution that provides complete health services for individuals; these encompass services, e.g., inpatient, outpatient, and emergency care. Hospital services as a service industry is a form of socioeconomic health service effort, which is a business that, although social in nature, is endeavored to obtain a surplus through professional management (Hasyim, 2005). In addition, Departemen Kesehatan RI (2003) defined nutrition and dietetics department as a hospital unit that is responsible for providing nutrient care based on condition of the patient, such as the clinical condition, nutritional status, and metabolism status. The scope of this department involves: 1) outpatient nutrition care, 2) inpatients nutrition care, 3) food management, and 4) nutrition research and development.

Food management in a hospital is a set of activities ranging from planning menus to distribution of food to the patients. This is aimed at achieving optimal health status by providing an appropriate diet. The processes of food management also involve steps, such as record keeping, reporting, and evaluation. Furthermore, the objective of food management in a hospital is to provide quality food and services based on the needs of the patients. The steps of food provision are divided into five, namely: selection of ingredients, storage of food, preparation of ingredients, management of ingredients, and distribution of food. These steps are prone to contamination from environment that can impact food safety and quality (Departemen Kesehatan RI, 2003).

Since food safety is central to one's health and life, it goes without saying that this aspect is considered as the rights of consumers (Winarno \& Surono, 2004). Implementation of the policy of food quality, food safety and qualified human resources that can monitor food management in preventing contamination is essential in ensuring food safety in a hospital (Damanik, 2012).

\section{Methods}

This study was conducted in the Department of Nutrition and Dietetics, Toto Kabila Regional Public Hospital, Bone Bolango. This qualitative study employed descriptive survey method; it was conducted by exploring sources of information to analyze implementation of HACCP principles. HACCP, as food contamination prevention system, functions as the study focus. The informants consist of eight people; three among them serve as key informants and five people as triangulation informants. Determination of informants in this study was conducted by using purposive sampling technique. The selected informant criteria is based on the principle of suitability and adequacy related to the implementation of food delivery in nutritional and dietetic service of the regional public hospital (henceforth called RSUD) Toto Kabila, Bone Bolango. Furthermore, data 
analysis were carried out using the Miles and Huberman method (Suryana, 2007), in which the collected data was made into a matrix and presented pieces of descriptive data which were then made into a checklist.

\section{Results and Discussions}

The observation focuses on the food management in the Department of Nutrition and Dietetics of RSUD Toto Kabila, Bone Bolango. Furthermore, the observation emphasized food processing and distribution as these processes are susceptible to contamination from the environment, which impacts food safety and quality. The data from the observation were corroborated by the result of interviews with key informants.

The results of the observation on the feasibility of processing hygiene and sanitation and distribution of food management in the study site are provided in Table 1 and Table 2 as follows.

$\%$ of feasibility $=55 \%$ (Below the standard). According to the principles of HACCP, the ideal steps of food processing comprise:

1) Identification of hazardous potential: cracks on the appliance, worker saliva, nail, and hair.

2) Control: wearing work equipment, cleanliness of processing venue, and worker hygiene.

3) Critical limits: temperature and duration of food processing.

4) Observation: observing food processing in site by employees of the nutrition department.

5) Corrective action: ensuring that food processing is in accordance with standard.

6) Verification: controlling that food processing is in accordance with standard.

7) Documentation: taking notes if things go wrong and recording corrective actions

Table 1. Observation of Sanitation and Hygiene Feasibility of Food Processing in Nutrition and Dietetics Department of RSUD Toto Kabila Bone Bolango in 2015

\begin{tabular}{|c|c|c|c|}
\hline No. & Standard Components & Yes & No \\
\hline & Food Processing & & \\
\hline 1. & Clean working attire & $\sqrt{ }$ & \\
\hline 2. & Wearing gloves & & $\sqrt{ }$ \\
\hline 3. & Wearing apron & & $\sqrt{ }$ \\
\hline 4. & Wearing mask & & $\sqrt{ }$ \\
\hline 5. & Cover mouth when coughing or sneezing & $\sqrt{ }$ & \\
\hline 6. & Remove jewelry during food processing & & $\sqrt{ }$ \\
\hline 7. & Not talking during food processing & & $\sqrt{ }$ \\
\hline 8. & Not mixing the appliances & $\sqrt{ }$ & \\
\hline \multirow[t]{2}{*}{9.} & Wash hands before food processing & $\sqrt{ }$ & \\
\hline & Food Processing room & & \\
\hline 1. & The floor and walls are clean & $\sqrt{ }$ & \\
\hline 2. & The room is separated from the bedroom or administration room & $\sqrt{ }$ & \\
\hline 3. & The room is insects free & $\sqrt{ }$ & \\
\hline 4. & The room has well-functioning ventilation & $\sqrt{ }$ & \\
\hline 5. & The room has sufficient lighting & $\sqrt{ }$ & \\
\hline 6. & The room has a washbasin & $\sqrt{ }$ & \\
\hline
\end{tabular}

Source: Primary Data, 2015 
Table 2. Observation Results of Sanitation and Hygiene Feasibility of Food Distribution at Nutrition and Dietetics department RSUD Toto Kabila Bone Bolango in 2015

\begin{tabular}{llll}
\hline No. & Standard Components & Yes & No \\
\hline 1. & Hospital food trolleys are water-proof & $\sqrt{ }$ & \\
2. & Hospital food trolleys have fine textures & $\sqrt{ }$ & \\
3. & Hospital food trolleys are easy to clean and have cover & $\sqrt{ }$ \\
4. & Food trolleys are anti-rust and leak-proof & $\sqrt{ }$ & \\
5. & Food trolleys have a temperature-control device & $\sqrt{ }$ \\
6. & Food trolleys have different food compartments & $\sqrt{ }$ \\
7. & The area for food trolleys remains clean & \\
8. & The area for food trolleys are dust free & $\sqrt{ }$ \\
9. & The trolleys are not contaminated by hazardous material, such as & $\sqrt{ }$ & $\sqrt{ }$ \\
10. & pesticides, etc. & $\sqrt{ }$ & \\
11. & Food trolleys are not used for distributing materials except food & $\sqrt{ }$ \\
12. & The food distribution routes are short & & $\sqrt{ }$ \\
13. & The food remains closed prior to serving to the patients & & $\sqrt{ }$ \\
14. & Employees wear all the necessary attires & $\sqrt{ }$ \\
15. & The trolleys are cleaned regularly & $\sqrt{ }$ \\
\hline
\end{tabular}

Source: Primary Data, 2015

$\%$ of feasibility $=60 \%$ (Below the standard). According to the principle of HACCP, the ideal steps of food processing comprise:

1) Identification of potential hazards: small rocks, soil, and insects.

2) Control: trolleys must remain covered and clean.

3) Critical limits: the duration and distance for transporting or distributing food to the patients.

4) Monitoring: employees in the nutrition department monitor the food management prior to distributing the food.

5) Improvement: trolleys maintenance, e.g., washing the trolleys and ensuring the density of trolley door.

6) Verification: re-checking the cleanliness and controlling the duration and distant during distributing the food.

7) Documentation: monitoring notes and checking during food distribution.

Food management hygiene and sanitation in catering needs to get attention starting from food procurement, processing, food handlers, equipment used, washing equipment, as well as serving and distributing food until the food is ready for consumption by consumers (Soeprapto \& Adriyani, 2009). It is revealed that the sanitation hygiene in RSUD Toto Kabila Bone Bolango in 2015 did not meet the standard. This is due to lack of infrastructure of the Nutrition and Dietetics Department. Such an issue is also due to the behavior of food handler that did not meet the standard of hygiene sanitation, such as talking during work and not wearing gloves or mask. This result is different from a study at Prof. Orthopedic Hospital Dr. R. Soeharso, Surakarta, in which at the time of processing, the processors already used aprons and headgear to reduce/prevent contamination in food processing (Ratna, 2009). One of the actions or healthy practices (such as food sanitation/food safety hygiene practices) is influenced by predisposing factors, namely level of knowledge. Knowledge is a very important domain to give rise to someone's actions or practices, because behavior based on knowledge will persist compared to actions that are not based on knowledge. Therefore, HACCP application is very much needed, such as through counseling activities. Direct practice of 
safe and healthy ways in materials preparation process, practical guidance provision on how to process, continuous monitoring and evaluation, is expected to improve the practice or behavior of patient food hygiene in hospitals, such as the use of work clothes, hand washing before and after work and not talk while doing work. Similarly, the issue regarding the food handler is also a contributing factor to the issue of food management in the study site (Puspita, Prawiningdyah, \& Nisa, 2010).

Food distribution is a series of food distribution activities according to the number of portions and types of food consumers are served (ordinary and special food). The distribution of food in the study site is also below the standard and some improvements are needed, e.g., the use of trolley and the distribution of food (the food compartment is mostly from the patients). This phenomenon may lead to food contamination. This result is different from a study that food in Surakarta Orthopedic Hospital is distributed by centralization. Distribution of food to Anggrek and Bougenville ward by means of centralization using cutlery such as plateau (Ratna, 2009).

Food Security and Quality Policy

Food safety is a community necessity, because it is hoped that through safe food, the community will be protected from diseases and other health problems. Food quality must be guaranteed, especially for hospitalized patients, whose bodies are weak and are very susceptible to various diseases, including foodborne diseases. Food safety is basically an effort to improve food sanitation, nutrition and safety (Nurlaela, 2011).

The result of interview and observation on documents signified that RSUD Toto Kabila, Bone Bolango had established a policy regulating quality that ensures food security. This was regulated in the Standard Operating Procedure (SOP), the Guidelines for Nutritional Management in Hospitals, 1990. For the HACCP, the nutrition department in RSUD Toto Kabila had a guidebook, i.e., Guideline for the Management of Food in Institution and the report of internship students that incorporate HACCP in the study site. Supervision of food quality based on the principles of prevention is believed to be superior compared to traditional methods which emphasized testing of the final product in the laboratory (Hermansyah, Pratikto, Soenoko, \& Setyanto, 2013).

Human Resources

Human resources are the implementing staff in providing food safety guarantees (HACCP) in the food delivery system in the nutrition unit. The Department of Nutrition and Dietetics in RSUD Toto Kabila, Bone Bolango had twelve employees with different educational backgrounds. The recruitment is carried out by the management of the hospital based on the needs of human resources and the capacity of the hospital. According to the result of the interview, the human resources in the department emphasized providing nutrition care, involving planning menus and designing diet for patients according to standard. However, the principles of HACCP to monitor the service were yet to be established. The human resources in the department considered that they are incapable of handling such works since they have yet to participate in workshops or seminars on HACCP. In fact, seven principles of HACCP have been conceptualized by the staffs, but they are yet to interpret it in documentation; this, however, is done manually without any record.

This result is different from the study in the Nutrition Unit at Margonda Bunda General Hospital in that one of the most decisive strategic effort to improve the existence and ability of employees is employee training. Training is a must for an organization and is a necessity in all fields, because the more educated and trained and the higher the motivation, the higher the productivity of work. Employee training is an important factor because it is a form of company investment. The way for employee development with training is to achieve company goals, namely to improve employee performance. The training activities are very important because aside to increasing knowledge and abilities, it will also raise the confidence of the nutrition unit personnel in the implementation of HACCP (Reni, 2012).

In addition to training or courses, to improve food quality in the organization of food, the health of workers is important. Worker health in the potential application of HACCP is a top priority. Health checks are essential when recruiting workers and while working, at least 
once every six months. So far, management is trying to recruit employees in the nutrition unit to meet the number of employees (Reni, 2012).

Standard Operating Procedure (SOP)

Standard operating procedures in the nutrition unit are made as a reference and guide in providing services to patients, employees and visitors. SOP contains a series of written instructions about routine or repetitive activities carried out by an organization. For this reason, SOP are also equipped with references, attachments, forms, diagrams and work charts (flow charts). The Department of Nutrition and Dietetics in RSUD Toto Kabila, Bone Bolango had designed its SOP and has been implementing it from the very first operation of the department. The SOP regulated all the food management processes to ensure food safety for the patients in RSUD Toto Kabila, Bone Bolango. Furthermore, the SOP is well-implemented by all the staffs in the department under the supervision of the head of the nutrition department. The department also sanctioned those who violate the SOP. Still, none of the employees has failed to comply with the regulations. SOP is also often referred to as an SOP manual that is used as a guide to direct and evaluate a job.

This result was in line with the study which stated the nutritional unit of Margonda Bunda Hospital has operational standards in every nutritional operational activity in the hospital. Each implementing officer has tried to carry out the SOP as much as possible, so that this supports the implementation of food safety guarantees, in this case that is HACCP. The good SOP implementation will show consistency of performance results, product results and service processes, all of which refer to employee ease and customer satisfaction (Reni, 2012).

Another study on Nutrition Installation Workers at Sultan Agung Islamic Hospital, Semarang stated that the implementation of the HACCP program was related to the practice of implementing SOP for food handling workers. Basically, all nutrition installation workers already know the benefits of implementing SOP properly, namely to reduce errors, failures and food contamination at work (Thoha, Lestantyo, \& Widjasena, 2018).

\section{Problem Identification}

Problem identification is among the processes attempted by the nutrition department of RSUD Toto Kabila, Bone Bolango which aimed at coping with issues in the department, especially food management. The department hold a meeting once a week to evaluate the management of food in the week and to find out whether there have been some issues or not. In identifying the issues or hazard, the department monitored all of the processes as it is among the steps of HACCP in food management. However, official documentation regarding the monitoring by the department has yet to be implemented.

Documentation of HACCP design results in patient food management that is compiled as authentic evidence of HACCP implementation. Maintaining documentation of the activities in a food safety management system based on HACCP principles is vital to its success. In the event that an establishment is implicated in a foodborne illness, documentation of activities related to monitoring and corrective actions can provide proof that reasonable care was exercised in the operation of the establishment (Zulfana \& Sudarmaji, 2008). Documenting activities provides a mechanism for verifying that the activities in the HACCP plan were properly completed (Grintzali \& Babatsikou, 2010). Some examples of records and documentation in the HACCP system are hazard analysis, determination of the CCP, setting of critical limits, CCP monitoring activities, and deviations and related corrective actions (Handoyo, 2013).

\section{Conclusions}

Generally, the Department of Nutrition and Dietetics in RSUD Toto Kabila, Bone Bolango had implemented the principles of HACCP, though it was not in accordance with the Indonesian National Standard. However, 
the internal of the department was the one who noticed the implementation of HACCP whereas the management of the hospital prioritized the implementation of SOP as a policy for food quality and security. It is suggested that the hospital implements HACCP according to the Indonesian National Standard (SNI) as well as provides supporting facilities.

\section{Acknowledgements}

We would like to thank The Nutritional and Dietetic Service of The Regional Public Hospital (RSUD) Toto Kabila, Bone Bolango who funded my study.

\section{References}

Arias, M. L., Monge, R., \& Chávez, C. (2003). Microbiological contamination of enteral feeding solutions used in Costa Rican Hospitals. ARCHIVOS LATINOAMERICANOS DE NUTRICION, 53 (3), 277-281.

Badan Standarisasi Nasional. (1998). Sistem Analisa Bahaya dan Pengendalian Titik Kritis (HACCP) serta pedoman penerapannya. Jakarta Pusat: Badan Standarisasi Nasional.

Buzby, J. C. (2002). Older Adults at Risk of Complications From Microbial Foodborne Illness. FoodReview , 25 (2), 30-35.

Damanik, I. R. (2012). Analisis Penerapan PrinsipPrinsip Hazard Analysis Critical Control Point (HACCP) Di Instalasi Gizi Rumah Sakit X Jakarta Tahun 2012. Depok: Fakultas Kesehatan Masyarakat Universitas Indonesia.

Departemen Kesehatan RI. (2003). Pedoman Pelayanan Gizi Rumah Sakit. Jakarta: Departemen Kesehatan RI.

Grintzali, G. P., \& Babatsikou, F. (2010). The significance of the application of Hazard Analysis Critical Control Point System in hospital catering. Health Science Journal , 4 (2), 84-93.

Handoyo, A. (2013). HACCP dan Penerapannya Dalam Industri Pangan. Semarang: Fakultas Teknik Universitas Negeri Semarang.

Hasyim, H. (2005). Hiperkes Dan Keselamatan Kerja Di Rumah Sakit (Tinjauan Kegiatan Keselamatan Dan Kesehatan Kerja Di Institusi Sarana Kesehatan). JMPK , 8 (2), 61-65.

Hermansyah, M., Pratikto, Soenoko, R., \& Setyanto, N. W. (2013). Hazard Analysis and Critical Control Point (HACCP) Produksi Maltosa Dengan Pendekatan Good Manufacturing Practice (GMP). JEMIS , 1 (1), 14-20.

Nurlaela, E. (2011). Keamanan Pangan Dan Perilaku Penjamah Makanan Di Instalasi Gizi Rumah
Sakit. Media Gizi Masyarakat Indonesia , 1 (1), 1-7.

Puspita, W. L., Prawiningdyah, Y., \& Nisa, F. Z. (2010). Penerapan Hazard Analysis Critical Control Point (HACCP) Terhadap Penurunan Bahaya Mikrobiologis Pada Makanan Khusus Anak Berbasis Hewani Di Rumah Sakit Umum Daerah Dr. Soedarso Pontianak. JURNAL GIZI KLINIK INDONESIA , 7 (1), 8-16.

Ratna, M. R. (2009). Evaluasi Manajemen Penyelenggaraan Makanan Institusi di Rumah Sakit Ortopedi Prof. Dr. R. Soeharso Surakarta. Surakarta: Fakultas Ilmu Kesehatan Universitas Muhammadiyah Surakarta.

Reni, S. M. (2012). Gambaran Potensi Penerapan Hazard Analysis Critical Control Point (HACCP) Di Unit Gizi RSU Bunda Margonda Tahun 2011. Depok: Fakultas Kesehatan Masyarakat Universitas Indonesia.

Soeprapto, F., \& Adriyani, R. (2009). Penilaian GMP dan SSOP pada Bagian Pengolahan Makanan di Katering X Surabaya dengan Metode Skoring sebagai Prasyarat Penerapan HACCP. The Indonesian Journal of Public Health , 6 (1), 30-37.

Sudarmaji. (2005). Analisis Bahaya dan Titik Kendali Kritis. JURNAL KESEHATAN LINGKUNGAN , 1 (2), 183-190.

Suryana, A. (2007). Tahap-tahapan Penelitian Kualitatif. Bandung: Fakultas Ilmu Pendidikan Universitas Pendidikan Indonesia.

Thoha, M., Lestantyo, D., \& Widjasena, B. (2018). Hubungan Program HACCP Dengan Praktik Keselamatan Dan Kesehatan Kerja Dan Workplace Hazard Pada Pekerja Instalasi Gizi Di Rumah Sakit Islam Sultan Agung, Semarang. JURNAL KESEHATAN MASYARAKAT , 6 (5), 610-616.

WHO. (2005). Penyakit Bawaan Makanan: Fokus Untuk Pendidikan Kesehatan. Jakarta: EGC.

Winarno, F. G., \& Surono. (2004). HACCP dan Penerapannya Dalam Industri Pangan. Bogor: M-BRIO PRESS.

Worsfold, D. (2001). A Guide to HACCP and Function Catering. The Journal of The Royal Society for the Promotion of Health, 120 (4), 224-229.

Zulfana, I., \& Sudarmaji. (2008). Hazard Analysis and Critical Control Point (HACCP) Pada Pengelolaan Makanan Pasien Rawat Inap Di Rumah Sakit Islam Lumajang. JURNAL KESEHATAN LINGKUNGAN , 4 (2), 57-68. 